\title{
Reforming the Gazettment of State Forest Area in Riau Province
}

\section{Pernando Sinabutar $^{1 *}$, Bramasto Nugroho ${ }^{2}$, Hariadi Kartodihardjo ${ }^{2}$, Dudung Darusman ${ }^{2}$}

\author{
${ }^{1}$ Graduate School of Bogor Agricultural University, Dramaga Main Road, Campus IPB Dramaga, Bogor, Indonesia 16680 \\ ${ }^{2}$ Department of Forest Management, Faculty of Forestry, Bogor Agricultural University, Academic Riang Road, Campus IPB \\ Dramaga, PO Box 168, Bogor, Indonesia, 16680
}

Received October 29, 2014 /Accepted December 18, 2015

\begin{abstract}
Controlling and determining ownership offorest area in Indonesia are done by units of forest area gazettment, which are ranging from designation to determination of boundary. The process is not quite easy and have tendency to be unsuccessful. The aim of study was to reveal the difficulty and to analyze series of measurements to reform. Descriptive data were analyzed qualitatively using strategy typology based on data collected through in-depth interviews, participant observation, and document review. The results showed that forest area gazettments had not been able to guarantee tenure as proof of ownership at local level dominated by proven un-written rights. Delineation process had potential conflict because it did not disclose claims process in a transparent manner. The mechanism of strengthening forest area did not meet the rules. This is because of low capability of Forest Boundary Committee (PTB). Therefore, it requires a set of actions namely strengthening of the PTB, separating duties between achievement and maintenance of legitimacy. To maintain the legitimacy needs the presence of managers at site level with strong legitimacy from government to collaborate with non-governmental organizations.
\end{abstract}

Keywords: forest area gazettment, Forest Boundary Committee (PTB), legal certainty, legitimacy

*Correspondenceauthor,email:damesinab@yahoo.co.id,tel.: +62-821-74783784

\section{Introduction}

Characteristics of state forest as common pool resources/CPRs require effective arrangements to have ownership and control of legal certainty. That assurance is one of important factors in forest management in Indonesia (Contreras-Hermosilla \& Fay 2006). Legally, the certainty is obtained through a process that starts from forest area gazettment of designation, boundary demarcation, mapping to the determination (Forestry Law/UU Number 41/1999 concerning on Forestry (Article 12), Government Regulation/PP Number 44/2004 concerning on Forestry Planning (Article 15), and regulation of the Minister of Forestry P.44/Menhut-II/2012 jo. P.62/Menhut-II/2013 concerning on Forest Area Gazzetment) and implementation delegated to Forest Boundary Committee/PTB. One of the duties and authority (regulation of the Minister of Forestry P.47/Menhut-II/2010 concerning the formation PTB) is to determine steps to resolve the rights of third parties stretch along the borders and in the forest area. Duties and authority was confirmed also in P.44/Menhut-II/2012 jo. P. 62/Menhut-II/2013, which did not only determine the steps to resolve, but also finalize the third party rights (Article 23). This means also that the duties and authority of the PTB is to realize the legitimacy. However, the Government has not been able to provide certainty of ownership and control (Efendi 2002; Contreras-Hermosilla \& Fay 2006), even policy since the beginning of potential conflict (Nugraha 2013). This proves that the government has not succeeded in implementing policies of forest area gazettment.
PTB does the forest area gazettment, and in fact, it relates to social and political issues. In terms of social, occupational boundaries are faced a claim that the evidence is dominated by un-written rights (Sirait et al. 2004: Contreras-Hermosilla \& Fay 2006; Nugraha 2013) that rely more on the story and history to legitimize the ownership and control of land (Affif 2005). The first one who cleared the land, were the owner (Saptomo 2004; Nugroho 2011). In positive law, recognition of rights existence of local communities would be difficult eventhough it is a necessity. From political point of view, it faces determination of regents as chairmen and other members of elements that are subject to regents ignoring professionalism. In addition, performance assessment based on realization of budget also directs institutions prefering to technical completion and legality. Budget allocation boundaries have not noticed social issues on field. The length of forest boundary in kilometers became the basis of budget allocation boundaries. It was concluded that there was a difference between field reality and intention of strengthening of forest policy. As consequently, legality and legitimacy are difficult to be realized.

Regardless of the difficulty, legality and legitimacy is essential to increase the success of natural resources management including forest (Frey \& Rusch 2014), to encourage management to become an effective CPRs (Kitamura \& Clapp 2013), to encourage agricultural investment, to boost economic growth in rural (Sivalai et al. 2012) and to improve the effectiveness of state forest settings. Therefore, it is necessary to have policy reforms and 
strengthen the implementation of state forest area. The Corruption Eradication Commission/KPK (2013) claims on verification activities, and collateral management to propose a formal legal approach through the scheme rural forest, community forest and social forestry (Nugroho 2011; Nugraha 2013) to build partnerships with government to improve the ownership regime (Dev Roy et al. 2011), and to strengthen the capacity of community (Ansoms et al. 2014). This study proposed a set of actions to answer the research objectives, namely to analyze the root of gazettment issue on forest area, to analyze the interaction between PTB and social problems of forest area confirmed; and to formulate a series of reform measurements of gazettment forest policy and its implementation.

\section{Methods}

The study was conducted in Riau Province (Figure 1). It needs to illustrate the typology of community (Safitri 2013), typology of social problem (Kartodihardjo et al. 2011), and bundle of rights (Ostrom \& Schlager 1996) taken from National Park/TN of Tesso Nillo and Limited Production Forest/HPT Pesemak DS and HPT of P. Setahun, S. Galang and Seberang in Riau Province and Protected Forest/HL of Sei Tembesi in Kepulauan Riau Province.

The research approach was qualitative (Creswell 1994) using case study method (Yin 2014). Data were collected through in depth interview, participants observation, and document review (Denzin 1989). Informants were determined purposively and the PTB in charge of organizing boundary which was partly done by snowball method (Sugiyono 2010). The amount of informants were 13 people from HL Sei Tembesi, 16 people from Tesso Nillo, and 12 people from HPT Pesemak DS and HPT P. Setahun, S. Galang, and Seberang. The informants consisted of Ministry of Forestry (MoF), universities, consultants, community and license holders. Validation of data was done by using triangulation of data sources and techniques (Sugiyono 2010). Then, the data were analyzed using descriptive qualitative; strategy typology (Lofland 1971 referred by Amin 2013) uses the analysis of bundle of rights (Ostrom \& Schlager 1996); Institutional analysis development/IAD Framework (Ostrom 2005) focusing on action arena (Polski \& Ostrom 1999), Clement 2010; Hardy \& Koontz 2010; Ostrom 2011), content analysis (Bungin 2001) and stakeholder analysis (Reed et al. 2009).

\section{Results and Discussion}

The issue of forest area gazettment root Content analysis is done on regulations of governing organizer boundaries of the Ministry of Forestry/MoF Number P.47/Menhut-II/2010; rules that concerning The Formation of PTB; regulation of the Director General of Forestry Planning Number P.6/VIIKUH/2011 concerning Technical Instructions Forest Area Gazettment, and Riau Governor's decision Number Kpts.662/v/2011 concerning The Establishment of Forest PTB District/City in Riau Province including regulation of the MoF Number P.44/Menhut-II/2012 jo. P.62/MenhutII/2013 concerns on Forest Area Gazettment, and it is found 3 things that have not resulted in effective performance of

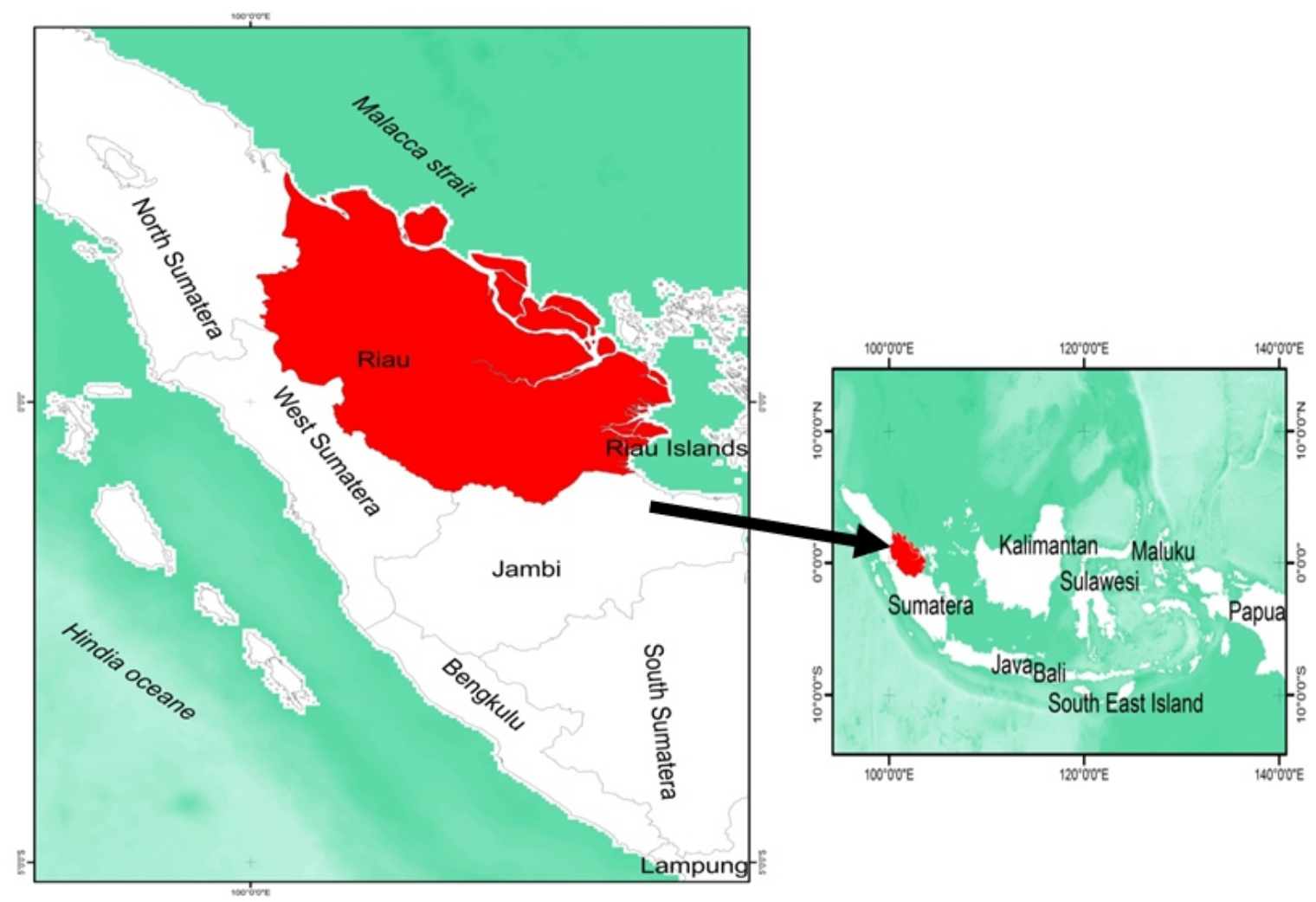

Figure 1 Study area. 
PTB. Firstly, by law, there are 3 basic legal designations of forest areas in the implementation of the boundary, namely: Forest Boundary Setting by Consensus/TGHK (1986), Province Spatial Developments Plans/RTRWP (1994), and spatial proposal (2009) used differently based on the interests of the PTB. Secondly, legality and legitimacy problems were solved by technical and administrative approaches, but the real problem is actually on institutional, social, and political aspects. In terms of institutions, there is no penalty if the PTB fails to complete forest boundaries. Then, from the social side, the claim was never resolved, and even less likely to reveal. In this case, the PTB has a weak understanding on complex societies. Diamond (2005) explains that the weakness in the understanding of complex societies can thwart policy. From the political side, the determination of Regents as the chiefs is very strong, while the other members should obey the commands of Regents in decision-making process. Thirdly, budget allocation does not include cost on social issues.

Three initiatives need to be raised are unilaterally cause of boundary, no claim to reveal in transparent manner, and let the mechanism of forest area gazettment not just according to the existing rules. The results showed, from a total of $11126.35 \mathrm{~km}$ forest area in Riau Province, there was a determination throughout $1850.67 \mathrm{~km}(16.63 \%$; 22 forest groups), but it has been delineated for $9499.02 \mathrm{~km}(85.37 \%$; 120 forest group). Factually, the results of these boundaries can not be used to minimize conflict, even claims continue to rise, as implemented in TN Tesso Nillo. PTB knows the claims, but the real problem is still not resolved. The document of forest delineation process /BATB and the map as results boundaries are signed without completing complex situation of societies. In Sei Tembesi protected forest, people do not make a claim because they understand that the land belongs to the exploitation agency/BP-Batam. However, limited forest production/HPT of Pesemak and HPT of P. Setahun, S. Galang, and Seberang are claimed that they are not disclosed, even the community are not allowed to mean the boundaries. These problems proved that the PTB as the organizer on institutional boundaries has not been effective. Therefore, institutional strengthening was necessary to combine formal and informal rules that involve all authorities (Satria et al. 2006).

Mechanism of forest area gazettment does not include completely all existing rules. The results showed that only $16.63 \%$ of the mechanism is in accordance with rules. Average boundary stops at BATB report and map boundaries results $(85.37 \%)$. In many cases, the mechanism stops even the definitive boundary due to limited time available. This was allowed and not revised, so the claim continued to grow. In addition, there were other unfixed mechanisms namely negotiation space, the announcement on penetration of temporary boundary and field duties. It is proven in the further research results.

"to my knowledge, meeting was only used to sign BATB and map results boundaries. We had no much time to know the contents of map presented, so we did not know whether the land in our village we entered is included in forest area or not. We also never reviewed the results and came to field together, and even never did the announcement. We sign the minutes of announcement and review the field result. Our presence was only caused by o invitation from Regents which was usually sent one day before meeting" (Village Head Sesap, October 2013).

Based on these findings, this study shows that $85.37 \%$ of forest in Riau Province does not have a legal basic. Furthermore, decision to discharge the Constitutional Court/MK Number 45/PUU-IX/2011 concerning of testing the constitutionality of Article 1 Paragraph 3 of Law Number $41 / 1999$ concerning of forestry jo. Law Number 19/2000 is quite important as legality of forest area through the establishment process.

The real world of forest area gazettment Property right applied at local level is that the first time anyone clears land, and he is the owner of the land (Saptomo 2004; Nugroho 2011). Then, the legitimacy of ownership and control of land are through stories or history (Affif 2005) eventhough it can not be evidenced in legal writen document (Sirait et al. 2004; Contreras-Hermosilla \& Fay 2006). In fact, it is recognized by local institution used by society to legitimize their rights. Unfortunately, such methods were not set in regulations of P.44/Menhut-II/2012 jo. P.62/Menhut-II/2013. These facts can be explained by the typology of knowledge communities (Safitri 2013), the typology of social problems (Kartodihardjo et al 2011) and the bundle of rights (Ostrom \& Schlager 1996) at the study sites.

Typology of community Communities along boundaries and inside the forest area have 2 names namely forest comunities and forest dwellers or forest users (Safitri 2013). Forest communities are a group of people who live in or around forest as well as harness and hang themselves in forest, for a long time, across generations, and sharedcollective awareness as a distinct group with other groups. Forest communities are not always customary law community. Forest dwellers/forest user are those that are individually located in and around the forest and benefiting forest in a particular period (usually shorter), without building shared norms and consciousness together as one community. The main motivation is usually economic interests. Typology of communities in TN Tesso Nillo, HL Sei Tembesi, HPT Pesemak DS, HPT P. Setahun, S. Galang, and Seberang is shown in Table 1. This typology of community illustrates that the existence of three groups of people in forest communities are more likely as a forest, which requires a separate policy outside of policy set forth in P.44/Menhut-II/2012 jo. P.62/Menhut-II/2013.

Typology of social problem In fact, forest areas tend to be "open access" and low recognition of rights of local communities has led to complex social problems. There are 4 typologies of social problems classified as heavy tenure conflicts, light tenure conflicts, problems of access to forest resources, and problems of illicit activity (Kartodihardjo et al. 2011). Typology of social problems for 3 groups forest are shown in Table 2. Typology of community and typology of social problem are used to describe the distribution of rights and authority to manage forest resources. Typology of community is used for distinguishing distribution of 
Table 1 Typology of communities in 3 forest groups

\begin{tabular}{|c|c|c|c|c|}
\hline \multirow{2}{*}{ Forest groups } & \multicolumn{2}{|c|}{ Definition of community } & \multirow{2}{*}{$\begin{array}{l}\text { Tendency } \\
\text { community }\end{array}$} & \multirow{2}{*}{$\begin{array}{l}\text { Typology of } \\
\text { community }\end{array}$} \\
\hline & Forest communities & Forest dwellers/users & & \\
\hline TN Tesso Nillo & $\begin{array}{l}\text { communities live in the forest for } \\
\text { generations for a long time, even } \\
\text { across generations. Then, there } \\
\text { were definitive villages and } \\
\text { indigenous communities called } \\
\text { "batin". }\end{array}$ & $\begin{array}{l}\text { Land is used for oil palm } \\
\text { and rubber gardening. }\end{array}$ & $\begin{array}{l}\text { People tend to } \\
\text { be in forest } \\
\text { communities, } \\
\text { but in certain } \\
\text { locations they } \\
\text { tend to be } \\
\text { forest } \\
\text { dwellers/user. }\end{array}$ & $\begin{array}{l}\text { It was based welfare } \\
\text { and cultural identity } \\
\text { and physical mastery. }\end{array}$ \\
\hline $\begin{array}{l}\text { HL Sei } \\
\text { Tembesi }\end{array}$ & $\begin{array}{l}\text { People who live have a certificate } \\
\text { from the headman land, while } \\
\text { community gardening, farming, } \\
\text { and farming systems acquire land } \\
\text { by purchase. }\end{array}$ & $\begin{array}{l}\text { Community gardening, } \\
\text { farming and brick } \\
\text { production (home } \\
\text { industry) are relatively } \\
\text { new (after 2000). }\end{array}$ & $\begin{array}{l}\text { People tended } \\
\text { as forest } \\
\text { dwellers/user, } \\
\text { unless } \\
\text { settlement } \\
\text { (forest } \\
\text { communities). }\end{array}$ & $\begin{array}{l}\text { It was based on } \\
\text { welfare which leads } \\
\text { to the mastery of } \\
\text { physical. }\end{array}$ \\
\hline $\begin{array}{l}\text { HPT Pesemak } \\
\text { DS, HPT S. } \\
\text { Setahun, S. } \\
\text { Galang, and } \\
\text { Seberang }\end{array}$ & $\begin{array}{l}\text { Communities have been lived in } \\
\text { forest areas for generations, but it } \\
\text { could not be evidenced in writing. }\end{array}$ & $\begin{array}{l}\text { There were relatively } \\
\text { small number of migrant } \\
\text { communities. }\end{array}$ & $\begin{array}{l}\text { It was more } \\
\text { likely as forest } \\
\text { communities. }\end{array}$ & $\begin{array}{l}\text { It was based welfare } \\
\text { and cultural identity } \\
\text { and physical mastery. }\end{array}$ \\
\hline
\end{tabular}

Table 2 Typology of social problems in 3 forest groups

\begin{tabular}{|c|c|c|c|c|}
\hline \multirow[b]{2}{*}{ Forest groups } & \multicolumn{4}{|c|}{ Typology of social problems } \\
\hline & $\begin{array}{l}\text { Conflict weight } \\
\text { tenure }\end{array}$ & $\begin{array}{c}\text { Conflict } \\
\text { lightweight tenure }\end{array}$ & $\begin{array}{l}\text { The problem of access to } \\
\text { forest resources }\end{array}$ & $\begin{array}{l}\text { The problems of } \\
\text { illicit activity }\end{array}$ \\
\hline TN Tesso Nillo & +2 & & $\sqrt{ }$ & $\sqrt{ }$ \\
\hline HL Sei Tembesi & & $\sqrt{ }$ & $\sqrt{ }$ & $\sqrt{ }$ \\
\hline $\begin{array}{l}\text { HPT Pesemak DS, HPT P. } \\
\text { Setahun, S. Gelang, and } \\
\text { Seberang }\end{array}$ & & & $\sqrt{ }$ & $\sqrt{ }$ \\
\hline
\end{tabular}

Adopted from Kartodihardjo et al. (2011)

ownership and access rights, while social typology is used for determining form of conflict resolution tenures. Then, the two were associated with the bundle of rights founded in TN Tesso Nillo, HL Sei Tembesi, and HPT Pesemak DS and HPT P. Setahun, S. Galang, and Seberang (Table 3). Typology of community, typology of social problem and bundle of rights are evidence of dilemma maintenance and management of state ownership as the CPRs. Every one wants to get a good result, but not everyone is willing to maintain its sustainability. In other words, there is competition in its use, and the Government enforces usage rules (Mutenje et al. 2011). Explanation of typology of community, the typology of social problems and the bundle of rights also proved that demanded perfection right P.44/Menhut-II/2012 jo. $\mathrm{P} .62 /$ Menhut-II/2013 is a necessity.

Interaction and role of PTB in forest area gazettment IAD Framework indicates that rules in-use have led to inequality interaction. Factually, stakeholder analysis (Reed et al. 2009) put the regent and BPKH as key players and elements of other members as subjects. The placement of elements negates role of other members in their interaction. Regent's power is bigger than other legitimate power and coercive power, and it is used to force as $\pm 75 \%$ element of PTB officers determined by the regents. Although BPKH and National Land
Agency/BPN are not structurally chosen by the regents, but in practice these institutions are subjects of the regent decision. BPKH has power to dominate the boundary activities to legitimate power, expert power and access to resources (knowledge, information, finance and technology) as consequence of their duties and functions. Regents' power and the BPKH domination are as result of policy decisions into a single concept without control and involvement of other members. As a result, interaction was only "an agreement" on signing BATB and map boundaries. The research finding proves that access theory by Ribot and Peluso (2003) mentioning the most dominant and the strongest actors (chairman of PTB and BPKH) would develop such mechanism namely relational and structural access that hegemony the decision.

There are at least 5 general explanations on the problems. Firstly, at the beginning, boundary has been positioned to complete technical aspects and only focus on budget received. Secondly, attributes community such as knowledge, values and norms are acepted, also level of homogeneity and ability to understand the un-equal gazettment policy to provide an opportunity that boundaries carried out unilaterally. In reality, equivalent values and norms are required for direct interaction (Hermans \& Thissen 2009). Thirdly, results of boundaries was not an agreement, 
Table 3 Bundle of rights in three forest groups

\begin{tabular}{|c|c|c|c|c|c|c|}
\hline \multirow{3}{*}{$\begin{array}{l}\text { Bundle of } \\
\text { rights }\end{array}$} & \multicolumn{6}{|c|}{ Forest functions/actor } \\
\hline & \multicolumn{2}{|c|}{ TN Tesso Nillo } & \multicolumn{2}{|c|}{ HL Sei Tembesi } & \multicolumn{2}{|c|}{ HPT Pesemak DS } \\
\hline & Office & User & Forestry service & User & $\begin{array}{c}\text { Forestry and } \\
\text { plantation office }\end{array}$ & User \\
\hline Access & $\begin{array}{l}\text { Management } \\
\text { rights }\end{array}$ & Rights across & Management rights & Rights across & $\begin{array}{l}\text { Management } \\
\text { rights }\end{array}$ & $\begin{array}{l}\text { Rights } \\
\text { across }\end{array}$ \\
\hline Withdrawal & Conservation & $\begin{array}{l}\text { Oil palm and } \\
\text { rubber }\end{array}$ & $\begin{array}{l}\text { Protected function } \\
\text { as watersheds }\end{array}$ & $\begin{array}{l}\text { Farming, } \\
\text { gardening, } \\
\text { settlements }\end{array}$ & $\begin{array}{l}\text { Management } \\
\text { rights for } \\
\text { commercial } \\
\text { purposes }\end{array}$ & $\begin{array}{l}\text { utilization } \\
\text { of } \\
\text { mangrove } \\
\text { and sago }\end{array}$ \\
\hline Management & $\begin{array}{l}\text { National Park } \\
\text { Management } \\
\text { Plan }\end{array}$ & - & $\begin{array}{l}\text { Medium term } \\
\text { management plan }\end{array}$ & - & $\begin{array}{l}\text { MediumTerm } \\
\text { Management } \\
\text { Plan }\end{array}$ & - \\
\hline Exclusion & $\begin{array}{l}\text { None, but if so, } \\
\text { it was in form } \\
\text { of MoU }\end{array}$ & - & $\begin{array}{l}\text { Have the right to } \\
\text { limit }\end{array}$ & - & $\begin{array}{l}\text { have the right to } \\
\text { limit }\end{array}$ & - \\
\hline Alienation & - & $\begin{array}{l}\text { System of } \\
\text { buying and } \\
\text { selling land } \\
\text { and } \\
\text { hereditary }\end{array}$ & $\begin{array}{l}\text { Transfer of rights } \\
\text { when scheme rural } \\
\text { forest, community } \\
\text { forest }\end{array}$ & $\begin{array}{l}\text { System of } \\
\text { buying and } \\
\text { selling land } \\
\text { and } \\
\text { hereditary }\end{array}$ & $\begin{array}{l}\text { Transfer of rights } \\
\text { when scheme } \\
\text { rural forest, } \\
\text { community forest } \\
\text { and social } \\
\text { forestry }\end{array}$ & $\begin{array}{l}\text { System of } \\
\text { buying and } \\
\text { selling land } \\
\text { and } \\
\text { hereditary }\end{array}$ \\
\hline
\end{tabular}

Adopted form Ostrom \& Schlager (1996)

but it was forced by power and domination, so it did not have legitimacy. Fourthly, boundaries does not reveal claims, so the results are not recognized and are susceptibled to overlapping tenure, licensing, even leading to resistance and conflict. Fifthly, rules in-use did not apply sanctions in enforcement, so that rules in-use were not demanding responsibility. In fact, sanctions and enforcement are absolutely needed to manage natural resources (Gibson et al. 2005). Enforcement of rules without enforcement of sanctions is not useful institutionally (Nugroho 2013). Based on these findings, this study shows that the role of PTB has not been effective yet and the rules in-use has not been able to steer the PTB interaction. The community attribute is not equal and contrary to norms. Thus, any rules will not be efficient if it is contrary to the norm. It can even lead to high transaction costs in the enforcement (Vollan et al. 2013).

Toward a framework for action Policy reforms on institution improve norms, rights, and setting boundaries for more real action. Sociologically, the reform should follow the processes that allow with the agreement signed. So that the challenges will emerge, especially for those who are usually too rigid bureaucracy and only see 'black and white' rules (Kartodihardjo 2007). During this time, the state forest rights enforcement has not been effective yet. Enforcement of rights by representatives (the last P.25/Menhut-II/2014 concerning the formation of PTB) will prioritize technical and administrative aspects. The situation is as a result of budget allocations which have not been based on social issues, usage of limited budget only one year, determination of element members attached to structural officials and boundaries documents are not open to public, including claims.

The emphasis of the policy reform is to secure tenure relating to typology of communities, typology of social problems, and bundle of rights of forest area confirmed, including improved budget allocation and completion time. The other reform effort is strengthening PTB and involving other agencies to deal with legitimacy. Adoption claims verification of KPK, P.44/Menhut-II/2012 jo. P.62/MenhutII/2013, then P.25/Menhut-II/2014, TAP MPR IX/2001 (agricultural reforms), scheme rural forest, community forest and social forestry proposed (Nugroho 2011) as well as proposal of Contreras-Hermosilla and Fay (2006) namely participatory delineation with community and long-term rentals can support the reform. Framework of policy reform measurement is shown in Figure 2. Explicitly, pressure is a separate task that reform legality and legitimacy. To determine legality of forest area, it can use the rule P.44/Menhut-II/2012 Jo P.62/Menhut-II/2013. Then, to get its legitimacy, the PTB should be empowered and government can legitimate site management organization. In detail, empowering PTB means strengthening position and corresponding membership duties and functions, defining their rights and obligations, enforcing rules, and determining of values and norms. This will encourage PTB and CPRs users to organize themselves in designing, monitoring, and enforcing the rules. Travers et al. (2011) showed that ability to devise, monitor, and enforce a set of rules among the resource users is very important to ensure the management of CPRs.

Arrangement legitimacy takes long time and should be carried out simultaneously, so it needs the presence of management unit at site level and involvement of nongovernmental organizations to conduct mediation and conflict resolution. So far, control of land by state is only reflected by delineation on a map, its presence at site level is never solely seen to be perceived. The presence of site level management institutions can strengthen local communities rights. It is in line with findings of Hansen (2011) that strengthening local communities rights is part of reform on forest management policy. Similarly, Larson (2010) said that recognition of indigenous peoples may be implicated in strengthening local community rights. Strong capacity (Andersson et al, 2013) is one of important indicators in achieving sustainable forest governance. 


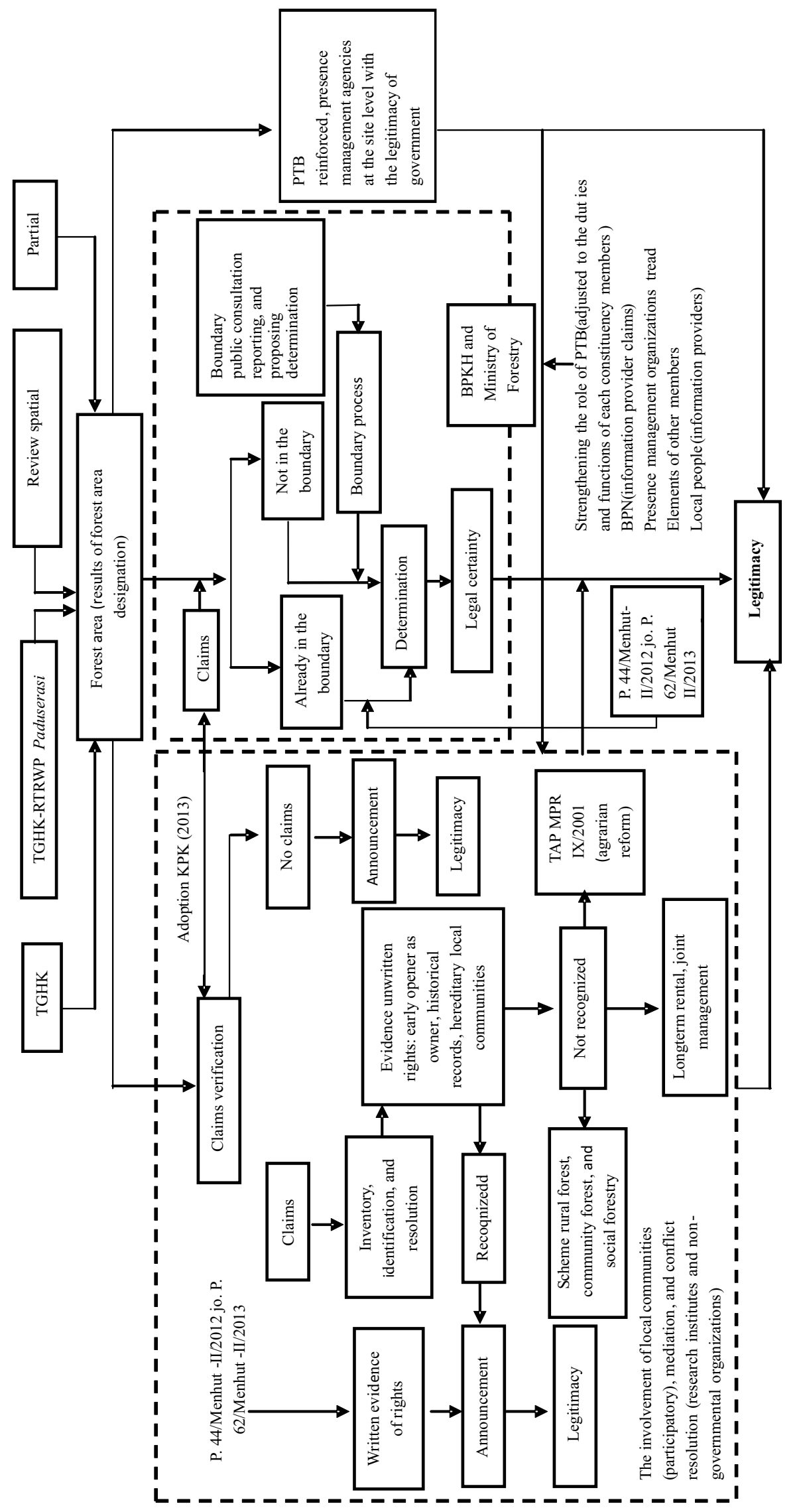

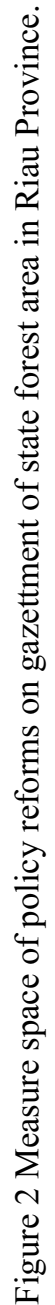




\section{Conclusion}

Characteristics as a state forest require setting up on effective, respected and enforceable CPRs to sort out the parties who are entitled and not entitled. To achieve the condition, government commissions PTB. As a result, less than $16.63 \%$ of boundaries have legitimacy. The truth claimed by government attaches to the legality, not legitimacy. Forest area gazettment issue reduces a question of law which can be overcome only by formal legalistic approach which is constructed by power. Boundaries only confirm legality of an area, but it is not linear with strong legitimacy as result of a single policy decision. Performance PTB was ineffective, even likely to fail, thus requiring policy reform. The reform includes separation of duties between principle of legality and legitimacy as a legal proof of recognition strengthening PTB and presenting organizations management tread.

\section{Acknowledgement}

The author extends deeply acknowledgment to the Centre for Forestry Education and Training, Ministry of Forestry of Republics of Indonesia for scholarship and support in budgetting and accomplishing this research.

\section{References}

Afiff S. 2005. Tinjauan atas konsep "tenure security", dengan beberapa rujukan pada kasus-kasus di Indonesia. Jurnal Ilmu Sosial Transformatif 20:227-249.

Amin M. 2013. Kekuasaan dan politik lokal (studi tentang peran Pemuda Pancasila dalam mendukung Syamsul Arifin dan Gatot Pudjonugroho sebagai calon Gubernur dan Wakil Gubernur Provinsi Sumatera Utara Periode 2008-2013) [dissertation]. Jakarta: Universitas Indonesia.

Andersson K, Benavides JP, Leon R. 2013. Institutional diversity and local forest governance. Journal of Environmental Science \& Policy 36:61-72. http://dx.doi. org/10.1016/j.envsci.2013.07.009.

Ansoms AN, Wagemakers I, Walker MM, Murison J. 2014. Land contestation at the micro scale: struggles for spacein the African Marshes. Journal of World Development 54:243-252. http://dx.doi.org/10.1016/j.worlddev.2013. 08.010

Bungin B. 2001. Content Analysis dan Focus Group Discussion dalam Penelitian Sosial di dalam Metodologi Penelitian Kualitatif: Aktualisasi Metodologis ke Arah Ragam Varian Kontemporer. Jakarta: PT. Raja Grafindo Perkasa.

Contreras-Hermosilla A, Fay C. 2006. Memperkokoh Pengelolaan Hutan Indonesia: Melalui Pembaruan Penguasaan Tanah, Permasalahan dan Kerangka Tindakan. Bogor: Bogor World Agroforestry Center and Forest Trends. http://www.rightsandresources.org/ documents/files/doc_1541.PDF[15 April 2014]
Clement F. 2010. Analysing decentralised natural resource governance: proposition for a "politicised" institutional analysis and development framework. Journal of Policy Science 43:129-156. http://dx.doi.org/10.1007/s11077009-9100-8.

Creswell JW. 1994. Research Design Qualitative \& Quantitative Approaches. California: Sage Publications, Inc.

Denzin NK. 1989. Intervretive Biography: Qualitatif Research Method. Series 17. London: Sage Publication.

Dev Roy AK, Alam K, Gow J. 2011. A review of the role of property rights and forest policies in the management of the Sundarbans Mangrove Forest in Bangladesh. Journal of Forest Policy and Economics 15:46-53. http://dx.doi. org/10.1016/j.forpol.2011.08.00.

Diamond. 2005. Collapse: How Societies Choose to Fail or Service. London: Penguin Books.

Frey UJ, Rusch H. 2014. Modeling ecological success of common pool resource systems using large datasets. Journal of World Development 59:93-103. http://dx.doi. org/10.1016/j.worlddev.2014.01.034.

Gibson CC, Williams JT, Ostrom E. 2005. Local enforcement and better forests. Journal of World Development 33(2):273-284. http://dx.doi.org/ 10.1016/j.worlddev. 2004.07.013.

Hansen CP. 2011. Forest law compliance and enforcement: The case of on-farm timber extraction in Ghana. Journal of Environmental Management 92(3):575-586. http://dx.doi.org/10.1016/j.jenvman.2010.09.021.

Hardy SD, Koontz TM. 2010. Collaborative watershed partnerships in urban and rural areas: Different pathways to success? Landscape and Urban Planning 95(3):79-90. http://dx.doi.org/10.1016/j.landurbplan. 2009.12.005

Hermans LM, Thissen WAH. 2009. Actor analysis methods and their use for public policy analysts. European Journal of Operational Research 196:808-818. http://dx.doi.org/ 10.1016/j.ejor.2008.03.040.

Kartodihardjo H, Nugroho B, Putro HR. 2011. Pembangunan Kesatuan Pengelolaan Hutan (KPH): Konsep, Peraturan Perundangan dan Implementasi. Jakarta: Debut Wahana Sinergi.

Kitamura K, Clapp RA. 2013. Common property protected areas: community control in forest conservation. Journal of Land Use Policy 34:204-212. http://dx.doi.org/ 10.1016/j.landusepol.2013.03.008.

[KPK] Komisi Pemberantasan Korupsi. 2013. Pendekatan Klaim Verifikasi untuk Percepatan Penetapan Kawasan 
Hutan Secara Definitif. Jakarta: Unit Kerja Presiden Pengawasan dan Pengendalian Pembangunan(UKP4).

Larson AM. 2010. Making the 'rules of the game': Constituting territory and authority in Nicaragua's indigenous communities. Land Use Policy 27 (4):1143-1152. http://dx.doi.org/10.1016/j.landusepol. 2010.03.004.

Mutenje MJ, Ortmann GF, Ferrer SRD. 2011. Management of non-timber forestry products extraction: Local institutions, ecological knowledge and market structure in South-Eastern Zimbabwe. Journal of Ecological Economics 70(3):454-461. http://dx.doi.org/10.1016/ j.ecolecon.2010.09.036.

Nugraha A. 2013. Mengakhiri Rezim Konflik Kehutanan: Momentum Pasca Keputusan MK. In: Darurat Hutan Indonesia. Mewujudkan Arsitektur Kehutanan Indonesia. Banten: Wana Aksara.

Nugroho B. 2011. Land rights of community forest plantation policy: analysis from an institutional perspective. Jurnal Manajemen Hutan Tropika 17(3):111-118.

Nugroho B. 2013. Reformasi institusi dan tata kepemerintahan: faktor pemungkin menuju tata kelola kehutanan yang baik. In: Kartodihardjo $\mathrm{H}$, editor. Kembali ke Jalan Lurus: Kritik Penggunaan Ilmu dan Praktek Kehutanan Indonesia. Yogyakarta: Nailil Printika.

Ostrom E, Schlager E. 1996. The Formation of Property Right. In: Hanna S, Folke C, Maler KG, editors. Rights to Nature. Ecological, Economic, Cultural, and Political Principles of Institutions for the Environment. Washington DC: Island Press.

Ostrom E. 2005. Understanding Institutional Diversity. Princeton and Oxford: Princenton University Press.

Ostrom E. 2011. Background on the institutional analysis and development framework. The Policy Studies Journal 39(1):7-27. http://dx.doi.org/10.1111/j.1541-0072.2010 $.00394 . x$

Polski MM, Ostrom E. 1999. An institutional framework for policy analysis and design. Paper on Workshop in Political Theory and Policy Analysis Departmen of Political Science, Indiana University, W98-27. http://mason.gmu.edu/ mpolski/documents/PolskiOstro mIAD.pdf(9 September 2014).

Reed MS et al. 2009. Who's in and why? A typology of stakeholder analysis methods for natural resource management. Journal of Environmental Management 90(5):1933-1949. http://dx.doi.org/10.1016/j.jenvman. 2009.01.001.

Ribot JC, Peluso NL. 2003. A theory of access. Rural Sociology 68(2):153-181. http:dx.doi.org/10.1111/j. 1549-0831.2003.tb00133.x

Safitri MA. 2013. Keadilan agraria di kawasan hutan: menafsirkan tanggung jawab negara terhadap reforma agraria. In: Hakim I, Wibowo LR, editors. Jalan Terjal Reforma Agraria di Sektor Kehutanan. Bogor: Puspijak Kementerian Kehutanan.

Saptomo A. 2004. Dibalik sertifikasi hak atas tanah dalam prespektif pluralisme hukum. Journal of Jurisprudence 1(2): 207-218.

Satria A, Matsuda Y, Sano M. 2006. Contractual solution to the tragedy of property right in coastal fisheries. Journal Marine Policy 30:226-236. http://dx.doi.org/10.1016/ j.marpol.2005.01.003.

Sirat M, Situmorang L, Galudra G, Fay C, Pasya G. 2004. Kebijakan Pengukuhan Kawasan Hutan dan Realisasinya. Bogor: World Agroferestry Centre. http:// outputs.worldagroforestry.org/record/1762/files/WP043 57.Pdf[28 April 2014].

Sivalai V, Khantachavana, Turvey CG, Kong R, Xia X. 2012. On the transaction values of land use rights in rural China. Journal of Comparative Economics 41:863-878. http://dx.doi.org/10.1016/j.jce.2012.11.003.

Sugiyono. 2010. Memahami Penelitian Kualitatif. Bandung: Alfabeta.

Travers H, Clements T, Keane A, Milner-Gulland. 2011. Analysis Incentives for cooperation: The effects of institutional controls on common pool resource extraction in Cambodia. Journal Ecological Economics 71:151-161. http://dx.doi.org/10.1016/j.ecolecon. 2011.08.020.

Vollan B, Sebastian P, Markus F. 2013. Analysis comanaging common-pool resources: Do formal rules have to be adapted to traditional ecological norms? Journal of Ecological Economics 95:51-62. http://dx.doi.org/ 10.1016/j.ecolecon.2013.08.010.

Yin RK. 2014. Studi Kasus, Desain dan Metode. Djauhi M, Mudzakir, translator. Translate from: Case Study Research: Desain and Methods. $13^{\text {th }}$ Ed. Jakarta. Rajawali Press 